\title{
Implementation Of Interprofessional Education To Improve Collaboration And Teamwork Capabilities
}

\author{
Prayudhy Yushananta ${ }^{1}$, Retno Puji Hastuti ${ }^{2}$ \\ \{prayudhiyushananta@poltekkes-tjk.ac.id ${ }^{1}$,retnopujihastuti15@gmail.com²
}

Department of Environmental Health, Poltekkes Kemenkes Tanjungkarang, Bandar Lampung, Lampung ${ }^{1}$, Indonesia ${ }^{1}$, Department of Nursing, Poltekkes Kemenkes Tanjungkarang, Bandar Lampung, Lampung, Indonesia ${ }^{2}$

\begin{abstract}
One of the problems in health care services is overlapping competencies due to insufficient cooperation between professions. Interprofessional learning (IPE) is required to foster a positive attitude between professions collaboration and teamwork skills between professions. The study was conducted to establish the application of IPE to increase students' collaboration and teamwork capability, using pre and post-design. The assessment of 148 students from four different professions, using instruments. The results were analyzed using Mean, SD, Min-Max, Wilcoxon Test. The results suggested an increase in scores of collaboration and teamwork, for about 51.11 and 20.67. Statistical analysis suggested a significant difference between before and after the program ( $\mathrm{p}$-value $=0.0001$ ). IPE can encourage positive interaction between professions, so that students have benefited, both in terms of their profession and in studying other professions. The early application of IPE is expected to lead to better health services in the future.
\end{abstract}

Keywords: Collaborative, Interprofessional Education, Teamwork

\section{Introduction}

Today, one of the problems in health care is overlapping competencies due to the lack of optimal cooperation between professions. This condition can cause tensions between professions and reduce service quality [1],[2]. On the other hand, an increase in public health problems due to an increase in the number and increasingly complex causes of factors also requires multidisciplinary cooperation in the health profession [3]. Quality of health care is the production of collaboration between patients and health care providers. The quality of health care depends on the personal factors of the provider and the patient, as well as factors related to the health organization. The availability of resources, collaboration, and cooperation affects the quality of care and patient outcomes [4].

Collaboration between professions in health care is considered beneficial because it allows for a more holistic approach and thus increases the chances of success. Collaboration is an effort to improve the quality of health services [5]-[7]. Therefore, each team member needs to have adequate knowledge about each other's profession. In traditional health education, different professions learn very little about each other. In interprofessional learning (IPE), students are allowed to acquire knowledge and skills from other professions and foster mutual respect [8]. IPE is proven to provide added value benefits for improving patient outcomes [9], as well as 
overcoming fragmentation in health care delivery and separation among health professionals [3],[10]-[12]. IPE education is a necessary step in preparing a health workforce ready for collaborative practice [11].

IPE is broadly defined as a teaching and learning process that encourages collaboration between two or more professions [10],[13]. This method can increase the knowledge, skills, and understanding of learners about interprofessional practice [2],[14], and has the potential to produce an effective and integrated team facilitating and optimizing health services [7],[10],[15]. IPE also provides input to educational institutions about the importance of independent learning, peer guidance, and work-based learning [16],[17]. Small interprofessional group learning provides more value than large group lecture formats [14].

Services that overlap between professions occur due to a lack of communication between health workers in teamwork so that services received by the community are not effective and efficient [18]. Interprofessional education is a prerequisite for building a collaborative practice environment [12] because it encourages positive interactions between professions and improves attitudes towards other professionals [1],[8],[19].

Interprofessional cooperation skills cannot be expected to develop naturally but must be trained early so that students have the knowledge and experience of working together in teams with other professions. The World Health Organization (WHO) has initiated an interprofessional educational framework and collaborative practice to improve the quality of health services [1],[2],[20]. For IPE to occur, there must be a willingness from all healthcare professionals to change the way they educate and practice. This of course requires changes in traditions, education, and practices which will ultimately change the paradigm [10].

In Indonesia, the application of IPE in health higher education institutions has not been widely used. The IPE method used is joint clinical learning at health care centers and hospitals, and health services with home visits [2],[3],[18],[20]-[28],[5]-[7],[9],[12],[13],[15],[17]. Although showing good results, the learning program is implemented intermittently, ranging from 2-12 hours per week. There is concern that this will affect perceptions and cooperation between professions.

Tanjung Karang Health Polytechnic is a vocational health higher education institution that produces professional graduates. We have tried to carry out interprofessional education which involves four skills or professions, namely nursing, midwifery, environmental health, and health analyst. Learning is carried out continuously, without interruption. The methods developed were a) forming groups of different professions at the beginning of the introductory session; b) conduct introductory sessions for 24 hours ( 8 hours per day); c) carry out field learning for 24 days continuously and live together; d) assign a facilitator to each group since the introductory session, and participate in the field learning with students.

This paper focuses on describing the improvement of students' collaboration and teamwork capabilities through the IPE method. It is important to socialize and research IPE learning that can facilitate increased student understanding and skills for communication, values , and ethics among professions, teamwork, roles and responsibilities, and other boundaries of professional authority. 


\section{Methods}

\subsection{Learning methods}

The research was conducted simultaneously with learning activities using IPE which was designed for 7 th-semester students ( 7 semesters out of a total of 8 ) from 4 vocations, namely environmental health, nursing, midwifery, health analyst, totaling 148 students. We did not take samples, so measurements were made of all the 148 students of the IPE program.

Learning is carried out in two stages, classroom learning as an introduction and field learning. Classroom learning is designed by combining students from different professions in small groups of 7-8 students. Through the incorporation from the start, it is expected that a process of socialization and interaction between individual students will occur. Furthermore, this group will continue to be together until field learning.

All student groups receive a 24-hours introductory session conducted over 3 days before field learning begins. So that the whole group receives the same information and has the opportunity to meet each other and the facilitators before their first day in the field. In the introductory session, each group will get an explanation of guidelines for field practice activities, data processing, problem-solving techniques, introduction to work areas, and interprofessional problem-solving simulations.

Field learning is carried out for 8 hours/day continuously for 24 days. The tasks that must be carried out during the field study are to map public health problems through surveys, data analysis, preparation of problem-solving plans, and health problem interventions. The planning of problem-solving to intervention is carried out with an interprofessional approach that involves all team members.

\subsection{Facilitator}

The facilitator is 21 lecturers who come from four different professions, environmental health, nursing, midwifery, and health analyst. The main task of the facilitator is to assist students, both in introductory and field learning sessions. Also, the facilitator provides an assessment of the students' collaboration and teamwork abilities, using the instruments that have been developed. Facilitator training is conducted to obtain the same knowledge, skills, and assessment of students.

2.3 Assessment and Instruments

Assessments ranging from $1-5(1=$ very poor; $2=$ poor; $3=$ fair; $4=$ good; $5=$ excellent $)$, were carried out twice using the pre and post design. The initial assessment is carried out at the beginning of the students being put together in small groups, and the final assessment when the program ends. The results of the assessment were analyzed using the SPSS 20.0 device, with Mean, SD, Min-Max, Wilcoxon Test.

The average score of collaboration and teamwork capabilities before and after the learning program was also used to create a quality rating scale, both for students and educational institutions. The range of score and weight/quality in Table 1. 
Tables 1. Score and Quality

\begin{tabular}{clcl}
\hline \multicolumn{2}{c}{ Collaborative } & \multicolumn{2}{c}{ Teamwork } \\
Score & \multicolumn{1}{c}{ Quality } & Score & \multicolumn{1}{c}{ Quality } \\
\hline $35.00-69.99$ & Poor & $20.00-39.99$ & Poor \\
$70.00-104.99$ & Fair & $40.00-59.99$ & Fair \\
$105.00-139.99$ & Good & $60.00-79.99$ & Good \\
$140.00-175$ & Excellent & $80.00-100$ & Excellent \\
\hline
\end{tabular}

The instrument was developed by representative lecturers from four professions, to assess students' teamwork and collaboration capabilities. The collaboration assessment contains 35 assessment items which are grouped into 1) roles, authorities, and responsibilities; 2) inter professions communication, while the teamwork assessment contained 20 assessment items (Table 2).

Table 2. Instruments for Interprofessional Education

\begin{tabular}{|c|c|}
\hline NO & EVALUATION ITEMS \\
\hline & Roles, Authorities, and Responsibilities \\
\hline 1 & Demonstrate professional skills with full responsibility \\
\hline 2 & Show the roles according to the authority and competence of each profession \\
\hline 3 & Recognizing the limitations of one's abilities, both knowledge, and skills \\
\hline 4 & Willing to hear and respect the opinions of others \\
\hline 5 & Able to involve other professions according to their expertise to solve patient problems \\
\hline 6 & $\begin{array}{l}\text { Develop ideas for coordination/collaboration with other professions according to their expertise } \\
\text { to solve patient problems }\end{array}$ \\
\hline 7 & Describe the uniqueness of his role according to his professional abilities in a responsible manner \\
\hline 8 & Describe strategies for building teamwork in providing health services \\
\hline 9 & Utilizing professionals in the team according to their expertise \\
\hline 10 & Providing services by ensuring client safety \\
\hline 11 & Providing services fairly \\
\hline 12 & Providing services effectively and efficiently \\
\hline 13 & Shows adaptive attitude/can control emotions in interactions between team members \\
\hline 14 & Able to clarify the role of each member in health services to clients and society \\
\hline 15 & Build trusting relationships between other professions \\
\hline 16 & Build interdependent relationships between other professions \\
\hline 17 & Participate actively in doing client problem solving \\
\hline 18 & Participate actively in building the capacity of the work team \\
\hline 19 & Demonstrate the ability to do creativity and innovation to optimize service to clients \\
\hline \multirow[t]{2}{*}{20} & Demonstrate unique abilities according to professional competence to optimize service to clients \\
\hline & Inter-Profession Communication \\
\hline 1 & Use effective communication tools and techniques \\
\hline 2 & Facilitate discussion and interaction between professions to improve team function \\
\hline 3 & $\begin{array}{l}\text { Able to communicate messages completely and systematically to clients (intent and purpose, } \\
\text { use of actions, choices, risk of action, work procedures) }\end{array}$ \\
\hline 4 & $\begin{array}{l}\text { Able to communicate messages completely and systematically to team members (intent and } \\
\text { purpose, use of actions, options, risk of action, work procedures) }\end{array}$ \\
\hline 5 & Able to communicate information about patients in a clear, confident manner \\
\hline 6 & Be able to communicate his opinion about the patient clearly and confidently \\
\hline
\end{tabular}




\begin{tabular}{|c|c|}
\hline NO & EVALUATION ITEMS \\
\hline 7 & Show respect for the opinions of others / the team \\
\hline 8 & Able to listen actively \\
\hline 9 & Encourage group members to express their ideas and opinions \\
\hline 10 & Able to provide appropriate, sensitive, constructive feedback to team members \\
\hline 11 & Able to receive feedback, respect team members' opinions, and other professional assessments \\
\hline 12 & Provide an explanation using language that can be understood rationally, \\
\hline 13 & $\begin{array}{l}\text { Contribute to creating effective communication, conflict management, and positive working } \\
\text { relations between professions }\end{array}$ \\
\hline 14 & Actively participate in conflict management between professions \\
\hline \multirow[t]{2}{*}{15} & Express opinions consistently about the importance of teamwork in health services \\
\hline & Teamwork \\
\hline 1 & Describe an effective team-building process \\
\hline 2 & Describe the importance of their respective roles ineffective team development \\
\hline 3 & Demonstrated the ability to build consensus ethically in solving service problems to clients \\
\hline 4 & Demonstrated the ability to build consensus ethically to solve problems in the group \\
\hline 5 & Involving related professions according to their expertise to solve problems \\
\hline 6 & Integrate knowledge and skills of other professions that are suitable in certain situations \\
\hline 7 & Effectively communicate to clients, the community about the results of team decisions \\
\hline 8 & Demonstrate an exemplary role in collaborative practice \\
\hline 9 & Be able to realize ideas \\
\hline 10 & Able to integrate ideas into collaborative practice \\
\hline 11 & Able to encourage team members in managing disagreements constructively \\
\hline 12 & Provide team members with constructive ideas for managing disagreements \\
\hline 13 & $\begin{array}{l}\text { Appreciate the skills, roles, and responsibilities of other professions in solving client, community } \\
\text { problems }\end{array}$ \\
\hline 14 & Collaborate and refer appropriately to solving client and community problems \\
\hline 15 & Reflecting on individual performance to improve one's performance \\
\hline 16 & Reflect on team performance to improve team performance \\
\hline 17 & $\begin{array}{l}\text { Using group improvement strategies to increase the effectiveness of collaboration between } \\
\text { professions }\end{array}$ \\
\hline 18 & Using available evidence/data to carry out teamwork practices \\
\hline 19 & Participate actively according to his expertise to solve problems \\
\hline 20 & Actively participate in teamwork according to their roles and functions in different situations \\
\hline
\end{tabular}

\section{Results}

The number of students participating in the study was 148 people with different skills, environmental health, nursing, midwifery, and health analysts, belonging to 21 groups. The highest proportion of expertise in midwifery was $44.6 \%$, the lowest was environmental health at $14.2 \%$. The number of participants is following the number of students in each professional program (Tabel 3). Based on gender, most of the students were female (89.2\%), following the majority of their origin education profession, are midwifery, and nursing. 
Table 3. Description of Student

\begin{tabular}{lcc}
\hline Variable & Frequency & Percent \\
\hline Profession & 21 & 14.2 \\
Environmental Health & 29 & 19.6 \\
Laboratory Analyst & 66 & 44.6 \\
Midwifery & 32 & 21.6 \\
Nursing & & \\
\hline Gender & 15 & 10.1 \\
Male & 133 & 89.9 \\
Female & & \\
\hline
\end{tabular}

The results of the collaboration assessment showed an increase of 51.11, from 86.05 (70.00$100.00)$ to 137.16 (62.00-83.00). In the teamwork, there was an increase of 20.67 , from 55.24 (42.00-64.00) to $76.11(62.00-83.00)$. The average score is also used to determine the quality of program success, both for individual students and at educational institutions. From Table 3, it can be seen that the collaboration of students before the IPE program is in the Fair category, and after the program has improved to be Excellent. The same as the teamwork ability, initially in the Good category, increases to Excellent (Table 4).

Tabel 4. Collaboration and Teamwork Score

\begin{tabular}{llllll}
\hline Variable & Mean & SD & Minimal & Maximal & Quality \\
\hline Pre Collaboration & 86.05 & 6.91 & 70.00 & 100.00 & Fair \\
Post Collaboration & 137.16 & 7.25 & 119.00 & 150.00 & Excellent \\
Pre Teamwork & 55.24 & 4.24 & 42.00 & 64.00 & Good \\
Post Teamwork & 76.11 & 3.82 & 62.00 & 83.00 & Excellent \\
\hline
\end{tabular}

We also classified the score of collaboration and teamwork by profession and gender to obtain information on capacity for each group (Table 5). In general, collaboration capabilities have increased in all professions. The average before was between 85.24-86.53; and after the IPE program becomes 136.14-137.95. Also in teamwork, It can be seen that the mean scores before the IPE program ranged from 54.10 to 55.82; and the value after is 75.52-75.75.

The distribution of the score of increased collaboration and teamwork is also not different based on gender. The average score of collaboration before the IPE program for male and female students was 84.67 and 86.21 ; thereafter to 138.27 and 137.03. The teamwork scores from 54.53 and 55.32; increased to 74.93 and 76.25. This description shows the IPE program can increase the collaborations between professions.

Statistical analysis is used to prove an increase in collaboration and teamwork capabilities, as well as a measuring tool for the success of learning programs. In the first step, an analysis is carried out to determine the normal distribution of the data using the Kolmogorov Smirnov Test. The results of the analysis obtained an abnormal distribution of data on the value of collaboration ( $\mathrm{p}$-value $=0.00$ ) and teamwork ( $\mathrm{p}$-value $=0.04)$, so it was decided to use nonparametric analysis techniques with the Wilcoxon Test. 
Tabel 5. Scores of Collaborative and Teamwork Based on Profession and Gender

\begin{tabular}{|c|c|c|c|c|c|c|c|}
\hline \multirow[b]{2}{*}{ Variable } & & \multicolumn{3}{|c|}{ Profession } & \multicolumn{3}{|c|}{ Gender } \\
\hline & & $\begin{array}{l}\text { Environ } \\
\text { mental } \\
\text { Health } \\
\end{array}$ & $\begin{array}{l}\text { Laborator } \\
\text { y analyst }\end{array}$ & $\begin{array}{l}\text { Midwifer } \\
\mathbf{y}\end{array}$ & Nursing & Male & Female \\
\hline \multirow{4}{*}{$\begin{array}{l}\text { Collaborative } \\
\text { Pre-Tes }\end{array}$} & Mean & 85.81 & 85.24 & 86.53 & 85.97 & 84.67 & 86.21 \\
\hline & SD & 7.35 & 6.12 & 6.66 & 7.98 & 7.58 & 6.84 \\
\hline & Min & 70.00 & 70.00 & 70.00 & 71.00 & 70.00 & 70.00 \\
\hline & Max & 100.00 & 97.00 & 99.00 & 98.00 & 97.00 & 100.00 \\
\hline \multirow{4}{*}{$\begin{array}{l}\text { Collaborative } \\
\text { Post-Test }\end{array}$} & Mean & 137.95 & 136.14 & 137.55 & 136.75 & 138.27 & 137.03 \\
\hline & SD & 7.89 & 6.27 & 7.15 & 8.06 & 8.57 & 7.12 \\
\hline & Min & 120.00 & 123.00 & 123.00 & 119.00 & 120.00 & 119.00 \\
\hline & Max & 150.00 & 148.00 & 150.00 & 150.00 & 148.00 & 150.00 \\
\hline \multirow{4}{*}{$\begin{array}{l}\text { Teamwork } \\
\text { Pre-Tes }\end{array}$} & Mean & 54.10 & 55.59 & 55.82 & 54.50 & 54,53 & 55.32 \\
\hline & SD & 5.21 & 4.25 & 3.77 & 4.22 & 5,53 & 4.09 \\
\hline & Min & 42.00 & 44.00 & 46.00 & 44.00 & 44.00 & 42.00 \\
\hline & Max & 60.00 & 62.00 & 64.00 & 60.00 & 62.00 & 64.00 \\
\hline \multirow{4}{*}{$\begin{array}{l}\text { Teamwork } \\
\text { Post-Tes }\end{array}$} & Mean & 75.52 & 75.83 & 76.59 & 75.75 & 74,93 & 76.25 \\
\hline & SD & 5.347 & 3.96 & 3.06 & 3.90 & 4,71 & 3.71 \\
\hline & Min & 62.00 & 66.00 & 72.00 & 66.00 & 66.00 & 62.00 \\
\hline & Max & 80.00 & 83.00 & 83.00 & 81.00 & 82.00 & 83.00 \\
\hline
\end{tabular}

The results of the analysis (Table 6) show a significant difference between the score of collaboration before and after the IPE program (p-value $=0.0001$ ). As well as, the teamwork score test before and after the IPE program also showed a real difference $(p$-value $=0.0001$ ). These results concluded that IPE can improve the students' capabilities in collaboration and teamwork.

Tabel 6. Wilcoxon Analysis

\begin{tabular}{lrl}
\hline \multicolumn{1}{c}{ Variable } & Z & p-value \\
\hline Colaboration_Post - Colaboration_Pre & $-10,595$ & 0,0001 \\
Teamwork_Post - Teamwork_Pre & $-10,761$ & 0,0001 \\
\hline
\end{tabular}

\section{Discussion}

The IPE program has had a positive impact on students in terms of their professional skills as well as in learning more about other professions. In this study, the increase in collaboration skills was 51.11, and teamwork capabilities were 20.67. Statistically, before and after the 
program showed a significant difference $(\mathrm{p}$-value $=0.0001)$. IPE learning shows added value compared to traditional methods in health education [16],[19],[22],[29].

Inter-professional education is developed from some educational theories, sociology, and psychology [29]. This method is used in health education to address fragmentation in health service delivery and the separation of health professionals [3],[10]-[12], is a step to prepare a health workforce ready for collaborative practice [11]. The focus is on health professionals and students who learn together from and about each other to improve collaboration and quality of patient care [29]. An interprofessional approach allows the sharing of professions and perspectives to form a common goal, namely restoring or maintaining health [21].

Inter-professional cooperation skills must be trained since the education period so that students have the knowledge and experience of working together in teams with other professions [1],[7],[20]. The interprofessional collaboration will improve the quality of health services [4],[5],[11],[19],[30] because it can avoid competency overlaps and reduce tensions between professions in providing services [1],[2]. The quality of health services is the result of the collaboration between patients and health service providers, which is influenced by personal factors from service providers and patients, as well as factors related to health organizations [4].

In student groups, there will be communication, exchange of ideas, a learning process, until finally finding an agreement to solve health problems [18],[24]. Good communication is the key to creating team collaborations [11],[12],[22],[25],[27],[31]. Perceptions of individuals and other professions are important factors that must be considered at the beginning of learning. Perception has an impact on attitudes and willingness to be involved in teamwork [32]. Poor perceptions will hinder the occurrence of communication between students [3],[17]. A positive attitude will arise if the program can provide opportunities for professional role development, independence, and self-esteem, learn about other professions, and learn how to work in teams [25],[27]. In this case, the role of the facilitator is very important in forming perceptions [18].

In IPE learning, the role of the facilitator greatly affects students' readiness. A facilitator must have the skill to optimize learning opportunities, appreciate differences and expertise, and be familiar with the dynamics of IPE learning [33],[34]. Facilitators who make disparaging comments and negative stereotypes will weaken the inter-professional message (29). Also, a facilitator must be an innovator, because students do not have experience in solving community health problems. Facilitators must understand the pedagogical methods and must provide students with constructive feedback [27]. A facilitator must also be able to act as an innovator in implementing IPE [13],[16],[18],[22],[33].

Developing professional skills is the most important goal of any learning program. The IPE concept is to provide opportunities for all students to improve their professional skills through a teaching and learning process that encourages collaboration between two or more professions. In this paper, we have proven that there is an increase in collaboration and teamwork capabilities in each profession and gender. Increased collaboration ability based on expertise ranges from 50.9-52.42; teamwork ranges from 20,23-21,42. In the gender group, increased collaboration capabilities ranged from 50.82 to 53.60; teamwork ranges from 20.40-20.93. These results indicate that IPE learning can be followed by all students, and can encourage positive interaction between professions, and improve attitudes towards other professionals. Every student has benefited, both in terms of their profession and in studying other professions. 
Lack of optimal cooperation between professions can cause tension [1],[2], the increasingly complex health problems and increasingly complex causal factors, require collaboration with multidisciplinary health professions [6]. IPE can promote teamwork in the future work life of students [32]. Thus, the application of learning the IPE method from an early age is expected to lead to better health services in the future. Interprofessional education should be introduced early during health education to promote collaborative understanding, and to counteract negative perceptions among health professionals [27].

Several IPE methods have been developed, but the IPE program we have developed seems to show better results. We combine students from different professions in small groups from the time of classical introductions. Furthermore, this group lives together during the field study. Facilitators are assigned to each group since the classical introduction period. In the field study, the facilitator lives with the group during the learning process. Facilitators are the key to success in the IPE program.

\section{Conclusion}

We have proven that the IPE method can enhance collaboration and teamwork capabilities. This method can encourage positive interaction between professions, improve attitudes towards other professionals, and get benefits from a professional perspective. Communication is the main key to creating collaboration and teamwork that begins with positive perceptions between students and between professions. The role of the facilitator is an important part of building student perceptions. Early adoption of IPE is expected to lead to better health services in the future.

Acknowledgments. We express our gratitude to the Director, Head of Department, Head of Study Program, and the entire academic community involved in the Tanjungkarang Health Polytechnic Interprofessional Education Practice.

\section{References}

[1] Thistlethwaite JE, Forman D, Matthews LR, Rogers GD, Steketee C, Yassine T. 2014. Competencies and Frameworks in Interprofessional Education. Acad Med [Internet]. Jun;89(6):869-75. Available from: http://journals.lww.com/00001888-201406000-00017

[2] Margison JA, Shore BM. 2009. Interprofessional Practice and Education in Health Care. Can J Sch Psychol. 24(2):125-39.

[3] Hastuti AB, Mulyani S. 2010. Efektifitas Program Pendidikan Interprofesional (IPE) Pada Persepsi Mahasiswa Mahasiswa. In: 8th International Nursing Conference "Education, Practice And Research Development In Nursing." p. 223-8.

[4] Mosadeghrad AM. 2014. Factors influencing healthcare service quality. Int J Heal Policy Manag. 3(2):77-89.

[5] Hind M, Norman I, Cooper S, Gill E, Hilton R, Judd P. 2003. Interprofessional perceptions of health care students. J Interprof Care. 17(1):21-34.

[6] Reeves S, Zwarenstein M, Goldman J, Barr H, Freeth D, Hammick M. 2008. Interprofessional education: Effects on professional practice and health care outcomes. Cochrane Database Syst Rev. (1).

[7] Averill MM, Dillon-Sumner L, Stergachis A, Sconyers J, Summerside N, Brazg T. 2019. Integrating public health students into interprofessional education. J Interprof Care [Internet]. 00(00):1-4. Available from: https://doi.org/10.1080/13561820.2019.1690436 
[8] Thistlethwaite J. Interprofessional education: A review of context, learning, and the research agenda. Med Educ. 2012;46(1):58-70.

[9] Shrader S, Jernigan S, Nazir N, Zaudke J. 2018. Determining the impact of an interprofessional learning in practice model on learners and patients. J Interprof Care [Internet]. 00(00):1-8. Available from: https://doi.org/10.1080/13561820.2018.1513465

[10] Smego R. 2010. Interprofessional education: a concept analysis. Adv Med Educ Pract [Internet]. Nov;75. Available from: http://www.dovepress.com/interprofessional-education-a-conceptanalysis-peer-reviewed-article-AMEP

[11] WHO. 2010. Framework for action on interprofessional education and collaborative practice [Internet]. WHO/HRH/HP. Hopkins D, editor. WHO. Geneva 27, Switzerland: WHO; Available from: http://www.who.int/hrh/nursing_midwifery/en/\%0ACopies

[12] Roberts LD, Davis MC, Radley-Crabb HG, Broughton M. 2018. Perceived relevance mediates the relationship between professional identity and attitudes towards interprofessional education in firstyear university students. $J$ Interprof Care [Internet]. 32(1):33-40. Available from: https://doi.org/10.1080/13561820.2017.1366896

[13] Barr H, Waterton S. 1996. Interprofessional Education in Health and Social Care in the United Kingdom. CAIPE.

[14] Cox M, Cuff P, Brandt B, Reeves S, Zierler B. 2016. Measuring the impact of interprofessional education on collaborative practice and patient outcomes. J Interprof Care. 30(1):1-3.

[15] D'Amour D, Oandasan I. 2005. Interprofessionality as the field of interprofessional practice and interprofessional education: An emerging concept. J Interprof Care. 19(SUPPL. 1):8-20.

[16] Hall LW, Zierler BK. 2015. Interprofessional Education and Practice Guide No. 1: Developing faculty to effectively facilitate interprofessional education. J Interprof Care. 29(1):3-7.

[17] Tyastuti D, Onishi H, Ekayanti F, Kitamura K. 2013. An Educational Intervention of Interprofessional Learning in Community Based Health Care in Indonesia: What did We Learn from the Pilot Study? J Educ Pract. 4(25):1-12.

[18] Zakiyyatul Fuadah D, Hapsara S, Sedyowinarso M. 2014. Kesiapan Mahasiswa untuk Belajar Kerjasama Interprofesi dalam Perawatan Antenatal (The Readiness of Students to Learn Interprofessional Teamwork in Antenatal Care). J Ners. 9(2):225-35.

[19] Thistlethwaite J, Moran M. 2010. Learning outcomes for interprofessional education (IPE): Literature review and synthesis. J Interprof Care. 24(5):503-13.

[20] Barr H, Helme M, Avray L D'. 2011. Health Sciences and Practice Subject Centre Developing Interprofessional Education in Health and Social Care Courses in the United Kingdom. Health Sciences and Practice Subject Centre.

[21] Bridges D, Davidson RA, Soule Odegard P, Maki I V., Tomkowiak J. 2011. Interprofessional collaboration: three best practice models of interprofessional education. Med Educ Online [Internet]. Jan 8;16(1):6035. Available from: https://www.tandfonline.com/doi/full/10.3402/meo.v16i0.6035

[22] Spaulding EM, Marvel FA, Jacob E, Rahman A, Hansen BR, Hanyok LA. 2019. Interprofessional education and collaboration among healthcare students and professionals: a systematic review and call for action. $J$ Interprof Care [Internet]. 00(00):1-10. Available from: https://doi.org/10.1080/13561820.2019.1697214

[23] Haugland M, Brenna SJ, Aanes MM. 2019. Interprofessional education as a contributor to professional and interprofessional identities. J Interprof Care [Internet]. 00(00):1-7. Available from: https://doi.org/10.1080/13561820.2019.1693354

[24] Kusumaningrum PR, Anggorowati A. 2018. Interprofesioanal Education (IPE) Sebagai Upaya Membangun Kemampuan Perawat Dalam Berkolaborasi Dengan Tenaga Kesehatan Lain. J Kepemimp dan Manaj Keperawatan. 1(1):14.

[25] Ponzer S, Hylin U, Kusoffsky A, Lauffs M, Lonka K, Mattiasson AC. 2004. Interprofessional training in the context of clinical practice: Goals and students' perceptions on clinical education wards. Med Educ. 38(7):727-36.

[26] Cunningham S, Cunningham C. 2019. Optimizing the observer experience in an interprofessional home health simulation: a quasi-experimental study. J Interprof Care. 1820. 
[27] Hylin U, Nyholm H, Mattiasson AC, Ponzer S. 2007. Interprofessional training in clinical practice on a training ward for healthcare students: A two-year follow-up. J Interprof Care. 21(3):277-88.

[28] Soemantri D, Sari SP, Wahyuni T, Ayubi D, Mulyono S, Adiatman M. 2019. Measuring the interprofessional collaborative competencies of health-care students using a validated Indonesian version of the CICS29. $J$ Interprof Care [Internet]. 00(00):1-9. Available from: https://doi.org/10.1080/13561820.2019.1697215

[29] Thistlethwaite J. 2012. Interprofessional education: a review of context, learning and the research agenda. Med Educ [Internet]. Jan;46(1):58-70. Available from: http://doi.wiley.com/10.1111/j.1365-2923.2011.04143.x

[30] Reeves S, Perrier L, Goldman J, Freeth D, Zwarenstein M. 2013. Interprofessional education : effects on professional practice and healthcare outcomes ( update ) ( Review ) SUMMARY OF FINDINGS FOR THE MAIN COMPARISON. Cochrane Database Syst Rev. 3(3).

[31] Fowler TO, Wise HH, Mauldin MP, Ragucci KR, Scheurer DB, Su Z. 2018. Alignment of an interprofessional student learning experience with a hospital quality improvement initiative. $J$ Interprof Care [Internet]. 00(00):1-10. Available from: https://doi.org/10.1080/13561820.2018.1455649

[32] Johnson KF. 2016. Interprofessional Education (IPE): Strategic Questions. Heal Interprofessional Pract [Internet]. 3(1):eP1095. Available from: http://commons.pacificu.edu/hip/vol3/iss1/8

[33] Barr H, Low H. 2011. Collaborative Practice through Learning Together to Work Together. 1-4.

[34] Barr H. 2002. Interprofessional Education: Today, Yesterday and Tomorrow. Paper 1., LTSN Health Sciences and Practice. Learn Teach Support Netw Cent Heal Sci Pract from UK Cent Adv Interprofessional Educ London, UK. 